\title{
Contract Broiler Farming
}

\author{
${ }^{1}$ Todsadee Areerat, ${ }^{2}$ Kameyama Hiroshi, \\ ${ }^{3}$ Ngamsomsuk Kamol and ${ }^{2}$ Yamauchi Koh-En \\ ${ }^{1}$ The United Graduate School of Agricultural Science, \\ Ehime University, 3-5-7 Tarumi, Matsuyama, Japan \\ ${ }^{2}$ Faculty of Agriculture, Kagawa University, Kagawa, Japan \\ ${ }^{3}$ Faculty of Agriculture, Chiang Mai University, Thailand
}

\begin{abstract}
In Thailand, poultry sector is the main economic growth of livestock sector, especially broiler production. The rapid expansion in broiler production has been made possible by the increase in the number of commercial farms or contract farming. The objective of this research was to understand better how contract farming works, who gets involved and why and who benefits from the agreement. The study is based on the broiler file survey in Chiang Mai province of Thailand. As the results, contract farming looks quite attractive for farmers as well as for private companies but most of the farmers complained about long waiting until the delivery of the next cycle of chicks have started.
\end{abstract}

Keywords: Broiler Production, Contract Farming, Benefit, Agreement, Farmer

\section{INTRODUCTION}

In the last twenty-five years, livestock production has become more industrialization in Thailand. According to the FAO report, poultry sector contributes more than $40 \%$ of livestock GDP. As indicated in Table 1 , during the past two decades the total production of poultry meat has increased at an annual rate of 5-6\%, the highest growth of all livestock products. Since broiler sector has become the industrialization in Thailand, some agribusiness companies have set up their own industrial farms and plantations. However, the industry is increasingly relying on a completely different mode of production to meet its needs. Instead of investing in their own production units, the companies sign a contract with the producer, specifying exactly the product they want, the way it will be produced, the quantity, the deadlines and the price (FAO, 2004).

Although commercial poultry have been started in Thailand as early as the 1970s with the largest agricultural enterprise-name Charoen Porkphand or C.P. company (Panglaykim, 1979; Hewison, 1981; Chng and Ross, 1993). Now more than 10 companies are dealing with this kind of contract farming such as Saha Farm, Sri Thai Livestock Company, Beta-grow (Isabeele and Kokeatkachom, 2007).
In 1974-1981, the number commercial broiler production has raised by the commercial farms from 36.4 billion to 288 million on birds (FAO, 2004). The rapid expansion in broiler production has been made possible by increase in the number of commercial farms, especially larger-scale chicken farms with more than 10,000 birds (Poapongsakorn and Panaiotov, 1985). However, most of poultry farms are highly concentrated in a few provinces in the central eastern and western region around Bangkok. Furthermore, the growth of contract farming in Northern region has been very slow poultry farms. Therefore, this study is to study the main problem they are facing and their implication for the risk of contract farms in north region. It also aimed at better understanding how contract farming works, who gets involved and who benefit from the agreement.

Moreover, there have been some studies on the contract broiler farming in Thailand but most of research focus on the province around the Bangkok of Thailand only. Researcher investigated the profit efficiency of the broiler production but did not explain the production cycle of contract farmer in Thailand. Furthermore, the limitations of the system and effectiveness of contract farming schemes are not critically assessed elsewhere. The present study aims to clarify the reason why contract farming in Chiang Mai province has advantage or disadvantage for the farmer.

Corresponding Author: Todsadee Areerat, The United Graduate School of Agricultural Science, Ehime University, 3-5-7 Tarumi, Matsuyama, Japan 
Table 1. Thailand meat production: annual growth rates

\begin{tabular}{llllr}
\hline Year & Chicken (\%) & Duck (\%) & Pig (\%) & Cattle (\%) \\
\hline $1980-1990$ & 6.69 & 2.54 & 3.00 & 2.70 \\
$1990-2000$ & 4.59 & 1.03 & 2.52 & -2.22 \\
$2000-2005$ & -5.07 & -5.24 & 5.85 & -9.28 \\
\hline
\end{tabular}

Source: NaRanong (2008)

Table 2. Characteristics of sample broiler farmers in Chiang Mai province

\begin{tabular}{lr}
\hline Particulars & Contract farmers \\
\hline No. of sample farmers & 52.00 \\
Average age of family-head (years) & 53.62 \\
Average education of family-head (years) & 6.25 \\
Occupation main-poultry (\%) & 84.62 \\
Occupation subsidy-poultry (\%) & 15.38 \\
Average experience (years) & 24.67 \\
Average area of the unit (acres) & 2.20 \\
\hline
\end{tabular}

Source: Filed survey data

\section{MATERIALS AND METHODS}

The study is based on the primary data collected from the broiler units in Chiang Mai province of Thailand. The survey covered 4 zones in Chiang Mai province such as North, East, South and West zone. Chiang Mai province is used to study because it closed a high concentration of various industries and contract farming had a contract with a large, medium and small farming in north region. A total of 52 farms were interviewed during October to November 2011 by the researcher. The name of the farmers, the districts where we conducted the study and the contracting company will be kept confidential to avoid exposing the farmers who took part. The questionnaire for the survey was constructed to ask for the detail about the poultry production on the farms. In particular, questions were included to determine the number of broilers and the use of input, such as labor, feed and capital.

\subsection{Characteristic of Broiler Farms}

The characteristic of sample broiler farmer given in Table 2 revealed that older age farmers, 54, were more engaged in broiler farming; and most of contract farmers had education at primary school (6 years). Average of contract farmers had poultry as the main occupation at $84.62 \%$. However, only $15.38 \%$ of farmers had agriculture as main occupation and poultry as subsidiary occupation.

\subsection{Linkage of Broiler Farmers with Companies}

The information on contract linkages of selected farmers with companies is present in Table 3.
Table 3. Linkages of contract broiler farmers with different companies (\% to total)

\begin{tabular}{lr}
\hline Name of company & Contract broiler farmers \\
\hline Charoen Porkphand or C.P. & 94.23 \\
Beta-grow & 3.84 \\
Saha Farm & 1.92 \\
\hline
\end{tabular}

Source: Filed survey data

It can be seen that C.P company had the maximum share in total contract (94\%), followed by Beta Grow (3.84\%). The share of other company, SaHa, was very low, only $1.92 \%$ in the total broiler farming.

\section{RESULTS}

\subsection{Production Structure of Contract farming}

In contract system, farmers have to invest in building a chicken house according to company specifications-company did not provide credit for the constriction of housing and the purchasing of equipment. Farmers sold the housing and equipment by themselvesthey loan money from bank (see in dotted line). Other inputs such as land, labor, housing and equipment, utilities and litter along with other fixed inputs are from farmer's side. In Chiang Mai provinces, wage contracts become the most popular form of contracts.

Most of the farmers started to build an open farm, i.e., a chicken house with good ventilation but with no air cooling system. In order to build that farm, most of them borrowed money from Bank. The investment range was 120,000 baht to 300,000 baht. However, since 1999 , companies have been requesting farmers to upgrade their farm into a "closed" system with an "evaporative cooling system" (EVAP). Since the outbreaks, companies have forced remaining subcontractors to invest in upgrading their holding facilities or to risk losing their contracts (Cocstales et al., 2006). It is a form of air conditioning with large fans on one and of the house and water dripping on the surface at the other end. This system increase growth and survival rates despite the tropical climate in Thailand. Moreover, it allows for higher density rearing thus decreasing average costs per birds (Haitook, 2006). According to the farmers, it has also reduced the birds' motility rate. 


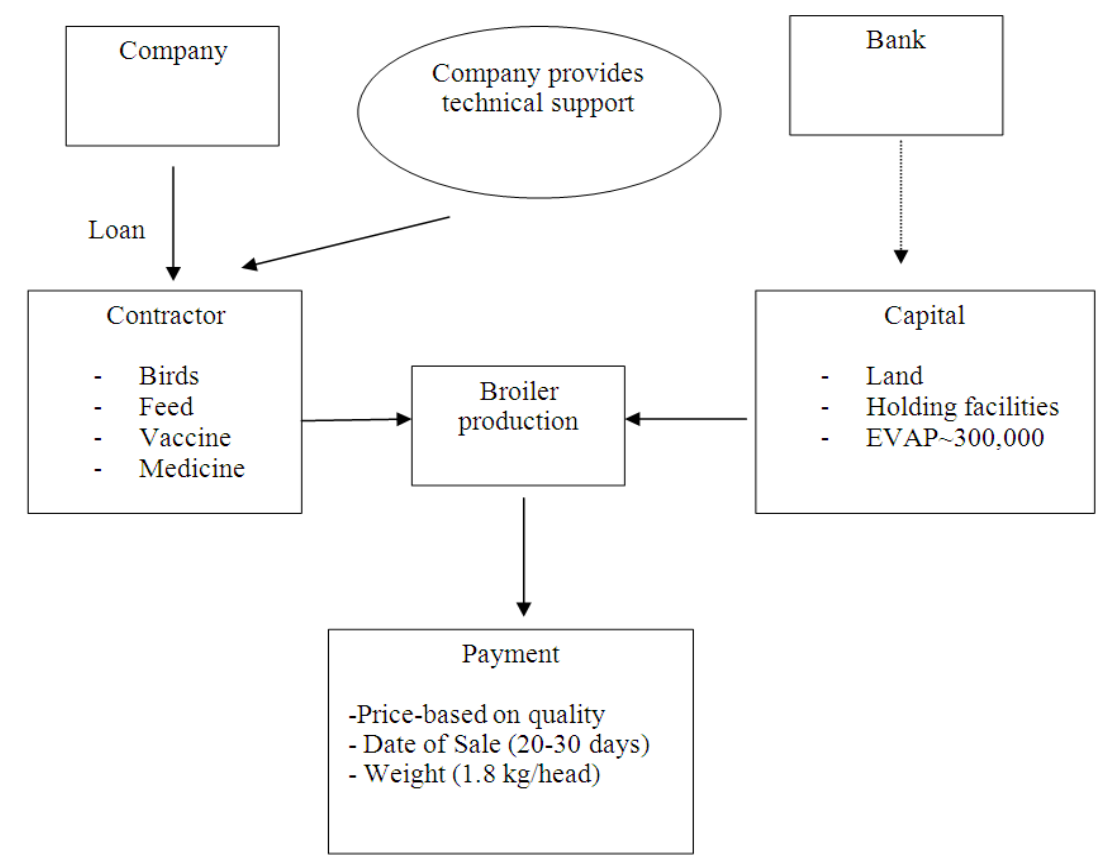

Fig. 1. The structure of the contract farmers Note: The picture adopt from Heft-Neal et al. (2008)

However, it is still a high investment costs for the contract farmers (around 200,000 baht). The average total investment of the chicken farmers that we met was 252,663.46 baht.

Once the farmers have their industrial farm, company provided the necessary all input to the farmer (as mention above). Inputs (birds, feed, vaccine, medicine) are loaned from company with cost taken out of payment. Farmers do not pay for the inputs when they receive them, but the costs of inputs are deducted from their pay from the company. However, they are not allowed to use any other input, such as replacing company feed by corn produced in the farm in order to reduce the costs. On the other hand, farmers have to follow very scrupulously the instructions of the company in term of quantity and quality of feed, when to give the medicine and so on.

The technical support also provided for broiler farmers by company-the integrators provided on chick rearing, feed rationing and disease control through their expert supervisors as free service (Fig. 1).

\subsection{Average Cost and Return of the Contract Broiler Farms}

The average cost and return of the contract broiler farms is summarized in Table 4. In this study, cost items consisted of variable costs (electricity, litter, gas, hire labor, tax and water) and fixed costs (i.e., housing and equipments). The cost of broiler production included not only paid but also unpaid item like depreciation costs. The costs were calculated per bird per batch. The Total Cost (TC) per bird per baht of contract farming was 16.14 baht.

The fixed costs of contract farmers were major costs ( about $51.98 \%$ ) of total costs production which most of them borrowed money from the Bank for Agriculture and Agricultural Co-operative or BAAC-5 to 10 years from 300,00 to 2 million bath.

However, the Variable Costs (VC) were $48.08 \%$ of the total costs for contract farming. Among the $\mathrm{VC}$ items, the cost of electricity and litter constituted the dominant share of the TC of production represent 28.96 and $21.87 \%$, respectively.

In term of revenue, farmers received an average per bird price of 26.62 baht and net return was 10.48 baht.The benefit-cost ratio was estimated at 1.6 baht per bird. The values obtained for the profitability indicators showed that broiler production for contract farming in Chiang Mai province is a profitable venture in rural area of Thailand.

However, farmers receive an income both from company payments and from selling chicken manure to neighbors or on the local market. While many expenses for inputs are incurred from the company (feed, day old chicks, vaccine and medicine). 


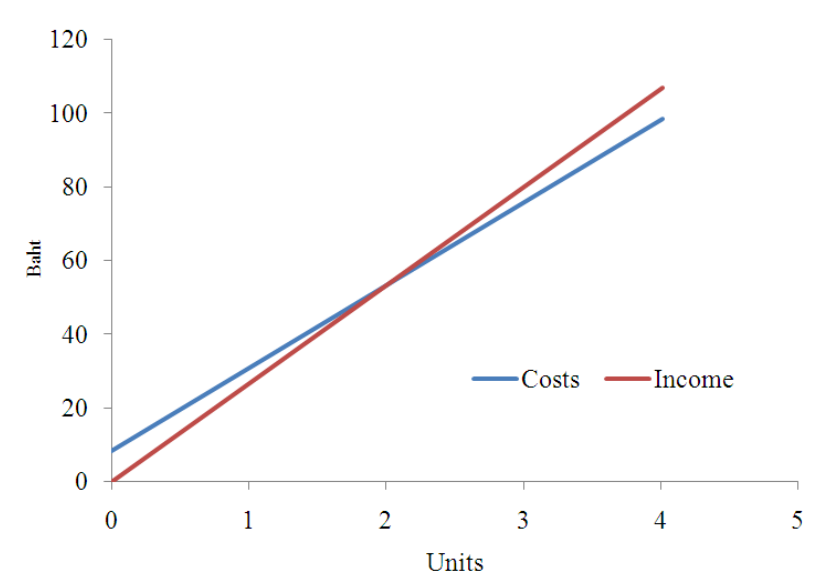

Fig. 2. Break-even point analysis Source: Author's calculation

Table 4. Broiler production costs of contract farm system

\begin{tabular}{lcc}
\hline Particular & Baht/bird & \% of total costs \\
\hline Total variable cost & 7.75 & 48.02 \\
-Electricity & 1.17 & 28.96 \\
-Litter & 3.53 & 21.87 \\
-Gas & 1 & 6.2 \\
-Hired labor & 0.86 & 5.33 \\
-Other cost & 1.19 & 7.37 \\
Total fixed costs & 8.39 & 51.98 \\
-Depreciation on housing & 4.35 & 26.95 \\
-Depreciation on equipment & 4.04 & 25.03 \\
Total Cost & 16.14 & 100 \\
Total Gross Returns & 26.62 & \\
-Broiler sold & 25.45 & \\
-Used litter and faces sold & 1.17 & \\
Net return & 10.48 & \\
(Broiler sold-Used litter & & \\
AND faces sold) & & \\
Benefit-cost ratio & & \\
(Total gross return / Total cost) & 1.6 & \\
\hline Note: 31 Baht $=1$ \$USD (September, 2011) Source: Author's \\
calculation
\end{tabular}

\subsection{Break-even point Analysis}

One of the most tools used in evaluating the economic feasibility of a new enterprise or product is breakeven point. The break-even point is the point at which revenue is exactly equal to costs. At this point, no profit is made and no losses are incurred. The break-even point can be expressed in term of unit sale. That is, the break-even units indicate the level of sale that is required to cover costs. One important aspect of break-even analysis is that it is normally not this simple.

In many instances, the selling price, fixed costs or variable costs will not remain constant resulting in a change in the break-even. It should be calculated on a regular basis to reflect changes in costs and prices and in order to maintain profitability or make adjustments in the product line (Hodgetts and Kuratko, 2000). The breakeven point in this study is obtained using the program, QM, written by Render et al. (2009).

In the Fig. 2, the red line represents the variation of income at varying levels of production activity. The blue line represents the total fixed costs in the firm. As income increases, variable costs are incurred, meaning that total costs (fixed + variable) also increase. At low level of income, costs are greater than income. At the point of intersection, 53.43 baht, costs are exactly equal to income and hence neither profit nor loss is made. Therefore, no profit more than 53.64 baht in gross income is generated per bird for producers.

\subsection{Contract Farming System: Advantage and Disadvantage}

Contract farming looks quite attractive for farmers. First of all, they do not have capital to set up, inputs (chicks, feed and medicine), production services are often supplied by company. The second is farmer can use the contract agreement as collateral to arrange credit with bank in order to fund inputs (housing, equipment). The third is farmer could sell chicks to the company. If they didn't work with company, they couldn't sell output to the company. The fourth is contract also gives farmers a sense of security; it is like getting a monthly salary. Furthermore, farmers work full time for the company and they depend entirely on the company for the inputs, the technology and the marketing of their whole production. Moreover, farmer's price risk is often reduced as many contract specify price in advantage (guaranteed and fix pricing) and also contract farming often introduced new technology to farmer to learn new skills.

However, consumer demands and market conditions can change company production and marketing strategies. Change in company strategies in these areas can cause change in bird placement schedules and size of birds' growth. These situations can and do cause variations in producer income.

Although contract farming was the gap between the cycles was raised. After catching the chickens, the farmer has to clean the house and get ready for the new cycle, but many of them complain about the long wait until the delivery of the next cycle of chicks. Farmer also complain about the conflicts with the company regarding issues such as quality of the feed and the input provided, delays for catch chicks and receive income from the company. 


\section{DISCUSSION}

Contract poultry production has been a good business for rural area of Thailand. This is in line with FAO (2004) that contract farmers for broiler did better than independent at comparable level of scale, because their forward price guarantees served them well in face of falling world prices. Among other, Heft-Neal et al., (2005) argued that contracting has potential to facilitate market access for poor farmers, increase product quality and promote more inclusive national economic growth. However, contract farming also had the problems such as delays in delivery or payment, quality deterioration. This agree with Baurle et al. (2007) argued that contract poultry farming has some disadvantage of problem as a production system such as delays in delivery or payment, quality deterioration.

Although the fixed costs were the major cost of total cost production in Chiang Mai province represents $51.98 \%$ of total production costs. This suggests that lower fixed costs may tend to hold down poultry costs, prices and favor industry expansion for contract farming. This in line with Hana (2010) that good management practices, the grower or farmers can reduce costs, thus increasing profitability. In variable costs, electricity and litter were the major costs of total cost production represent 28.96 and $21.87 \%$. This result agreed with Zakir (2008), the important costs in contract farming were electricity charge and litter material costs.

\section{CONCLUSION}

The livestock industry and especially the broiler sector in Thailand is presented as a success story due to the dramatic increases in production and exports over the last decades. This study discusses a survey-based assessment of the contract farming of broiler in Chiang Mai province of Thailand. Input marketing contracts cover supply of inputs and services.

The fixed costs of contract farmers (i.e. housing and equipments) were 51.98 percent of total costs production which their paid money for bank between 5 to 10 years. This suggests that lower fixed costs may tend to hold down poultry costs and prices and favor industry expansion for contract farming. Therefore, government should subsidy in form of low interest rate to reduce their costs for building chicken house and equipment.

The main advantage of production-marketing contract to the producer is farmer's price risk is often reduced as contract specifies price in advantage (guaranteed and fix pricing), contract farming often introduced new technology to farmer to learn new skills and company invest inputs. However, sharing of production and risk and mode of payment for input vary among the quantity and time.

Contract farming also had the problems such as delays in delivery or payment, quality deterioration which are emerging from the applications. Therefore, sponsor company should pay remunerative prices to the producer in view of a huge investment made and should provide insurance to the birds. The government can extend its support by paying part of capital cost to the broiler farmers.

We hope that this research will draw more attention to this changing work relationship in the food production chain and will help independent farmers as well as contract farmers to defend their right.

\section{REFERENCES}

Baurle, I., L. Smith, D.C. Baulcombe and C. Dean, 2007. Widespread role for the flowering-time regulators FCA and FPA in RNA-mediated chromatin silencing. Science, 318: 109-112. DOI: 10.1126/science. 1146565

Chng, D. and K. Ross, 1993. Growth Strategies of the Charoen Pokphand Group, Thailand. 1st Edn., Swinburne University of Technology, Hawthorn, ISBN-10: 0855907290, pp: 35.

Cocstales, A., P. Gerber and H. Steinfeld, 2006. Underneath the Livestock Revolution. 1st Edn., Rome, Italy, pp: 6.

FAO, 2004. Project on livestock industrialization. Trade and social-health-environment impacts in developing countries, IFPRI-FAO.

Haitook, T., 2006. Study on Chicken Meat Production for Small-Scale Farmers in Northeast Thailand. 1st Edn., Kassel University Press, Kassel, ISBN-10: 9783899582383, pp: 164.

Hana, C.F., 2010. An Assessment of the Potential Profitability of Poultry Farms: A Broiler Farm Feasibility Case Study. 1st Edn., University of Tennessee at Martin, Martin, USA., pp: 70.

Heft-Neal, S., D. Roland-Holst, S. Sriboonchitta, A. Chaiwan and J. Otte, 2005. Promoting rural livelihoods and public health through poultry contracting: Evidence from Thailand. Natural Resource Manage. Policy, 36: 327-351.

Heft-Neal, S., J. Otte, W. Pupphavessa, D. Roland-Holst and S. Sudsawasd et al., 2008. Supply chain auditing for poultry production in Thailand. Rural Development Research Consortium. 
Hewison, K.J., 1981. The financial bourgeoisie in Thailand. J. Contemporary Asia, 11: 395-411. DOI: 10.1080/00472338185390271

Hodgetts, R.M. and D.F. Kuratko, 2000. Effective Small Business Management. 7th Edn., John Wiley and Sons New York, ISBN-10: 047000343X, pp: 752.

Isabeele, D. and W. Kokeatkachom, 2007. Contract farming in Thailand: A view from the farm. Chulalongkorn University, Bankok-Thailand, pp: 1-24.

NaRanong, V., 2008. Structural Changes in Thailand's Poultry Sector and Its Social implication. Thailand Development Research Institute, Bangkok, Thailand.

Panglaykim, J., 1979. Emerging Enterprises in the AsiaPacific Region, Jakarta: Center for Strategic and International Studies. Cornell Southeast Asia, United State.
Poapongsakorn, N. and T. Panaiotov, 1985. The Commercial Broiler and Swine Industries in Thailand. 1st Edn., Agricultural Development Council, Bangkok, pp: 299.

Render, B., R.M. Stair Jr., M.E. Hanna and T.N. Badri, 2009. Quantitative Analysis for Management. 10th Edn., Pearson Education India, ISBN-10: 8131723739, pp: 764.

Zakir, S., 2008. Management of contract farming livestock: A case of poultry industry. University of Agricultural Science, India. 